\title{
Aspects of the History of the International Union of Crystallography
}

\author{
D. W. J. Cruickshank \\ Chemistry Department, UMIST, Manchester M60 1QD, England. E-mail: dwj_cruickshank@email.msn.com
}

(Received 14 August 1998; accepted 1 September 1998)

\begin{abstract}
The first General Assembly and Congress of the IUCr was held at Harvard in 1948. The background to that meeting and the subsequent history of the Union are outlined. The IUCr journal Acta Crystallographica has grown enormously in the last 50 years. The International Tables for Crystallography in their various volumes have been a remarkable achievement. Highly successful scientific Congresses have been held every three years.
\end{abstract}

\section{Introduction}

Fifty years ago from 28 July to 3 August 1948, the International Union of Crystallography held its first General Assembly and Congress at Harvard University, Cambridge, Massachusetts, USA. The meeting was held at the joint invitation of the American Society for X-ray and Electron Diffraction, and the Crystallographic Society of America. It was financially supported by generous donations from American industrial and other organizations. 310 crystallographers took part. In the scientific Congress, 83 papers were presented and there were three Lecture reviews: by Bernal on proteins, by Wyckoff on the electron microscopy of crystals and, most memorably, by Shull on the new field of neutron diffraction.

Harvard July 1948 was indeed the first formal meeting of the Union, but even then the Union was already a going concern, thanks to the work of committees formed at an international gathering of crystallographers held in London in July 1946 - just a year after the end of World War II. But one must go back pre-war for the first international cooperations.

Durward Cruickshank joined E. G. Cox's chemical crystallography group at Leeds University in 1946. He published extensively in Acta Crystallographica from 1948 onwards on topics in crystal structure refinement. From 1962 to 1967, he was Joseph Black Professor of Chemistry at Glasgow University. In 1967, he moved to UMIST. Since retirement, he has helped in the revival of the Laue method and latterly has been working on protein structure precision. He was an Editor of the 1992 IUCr Memorial Volume for Paul Ewald. He was IUCr Treasurer 1966-1972 and General Secretary 1970-1972.

C) 1998 International Union of Crystallography

Printed in Great Britain - all rights reserved
In this short article, it is possible only to cover rather briefly some aspects of the history of the Union. Excellent accounts of the formation and early development of the IUCr and of Paul Ewald's part in the building of the crystallographic community are given by Kamminga $(1989,1992)$. In places, my account is a direct summary of Kamminga. The chapters by Ewald, McLachlan, Evans, Buerger and Shoemaker in Crystallography in North America (McLachlan \& Glusker, 1983) give lively accounts of the background to the early history of the IUCr. Articles by Ewald (1944, 1962, 1977) add to the story. Annual Reports of the Executive Committee of the IUCr and Reports of the General Assemblies in the pages of Acta Crystallographica provide regular details.

\section{The situation by 1939}

The scientific foundations of modern crystallography were laid in 1912 by Laue's discovery of X-ray diffraction followed immediately by the invention of crystal structure analysis by the two Braggs - son and father. The subject developed rapidly and in 1929 there was a Faraday Society meeting in London on Crystal Structure and Chemical Constitution. Afterwards, Sir William Bragg convened a meeting to discuss the issues that required closer cooperation between crystallographers at an international level. Three committees were set up to investigate a coordinated abstracting scheme, the preparation of standardized space-group tables and the standardization of crystallographic nomenclature.

The Tables Committee consolidated its plans at a 12 day meeting organized by Ewald and Bernal and held at Paul Niggli's institute in Zurich in 1930. The eventual outcome was the publication in 1935 of the splendid two volumes of the Internationale Tabellen zur Bestimmung von Kristallstrukturen (International Tables for the Determination of Crystal Structures). Carl Hermann as Editor led a team of 18 contributors from 6 countries. One vital piece of work concerned the nomenclature for the 230 space groups. The introduction of the HermannMauguin notation in parallel with the older Schönflies notation was a major advance. A symbol such as $I 22_{1} 3$ is vastly more informative than $T^{5}$.

The Strukturbericht, edited at first by Ewald and Hermann and then by Hermann alone, provided critical 
summaries of structure papers covering the years 1913 to 1939.

The internationally recognized but commercially owned journal Zeitschrift für Kristallographie, which had been founded by Paul Groth in 1877, had Paul Niggli as its Editor-in-Chief.

\section{1941-1946}

World War II put a stop to many crystallographic activities, but not completely. In the USA in 1941, the American Society for X-ray and Electron Diffraction (ASXRED) was founded. In the United Kingdom, the X-ray Analysis Group (XRAG) of the Institute of Physics was set up in 1943. Its first meeting was held at Oxford in March 1944. Ewald was invited to give the evening lecture (Ewald, 1944). After a historical survey of some of the stages of X-ray crystallography, he ended with a strong plea for the formation of an international society or union which would represent the new crystallography. The union he envisaged would be responsible for publishing an international journal of crystallography as well as archives, abstracts, spacegroup tables and structure reports.

At about the same time, ideas for a crystallographic journal were being developed in the USA. Happily, in October 1944 Martin Buerger of ASXRED wrote to Henry Lipson of XRAG and thus the two groups made contact. By April 1945, XRAG had a Publications SubCommittee under Sir Lawrence Bragg that looked seriously at the possibilities. Their views were communicated both to the Americans and to Russian crystallographers. The Russians were keen for an international journal of crystallography to be founded to replace the then defunct Zeitschrift für Kristallographie. Once the war was over, there was a widening circle of correspondence with leading crystallographers in several countries. The upshot was an international conference held in London in July 1946 arranged by XRAG. This had both a scientific programme ' $\mathrm{X}$-ray Analysis During the War Years' and business meetings to explore the starting of a journal and the formation of an International Union.

\section{The 1946 meetings and the birth of the Union}

The London meeting was attended by about 330 crystallographers, mostly from the UK, but at least 65 came from 12 other countries. The scientific programme was spread over 3 days in what would now be considered a rather leisurely manner. Unfortunately, no photographs from the London meeting have reached the Union's archives. But a good flavour of the gathering can be found in Dan McLachlan's chapter in Crystallography in North America.

London was followed by a science meeting in Leeds University, where there were four X-ray laboratories. A
Table 1. World Directory of Crystallographers

$\begin{array}{lllll}\text { Number } & \text { Year } & \text { Countries } & \text { Entries } & \text { Editor } \\ 1 & 1957 & 52 & 2208 & \text { W. Parrish } \\ 3 & 1965 & 51 & 5037 & \text { D. W. Smits } \\ 5 & 1977 & 71 & 7638 & \text { S. C. Abrahams } \\ 7 & 1986 & 69 & 8968 & \text { A. L. Bednowitz } \\ 10 & 1997 & 74 & 7959 & \text { Y. Epelboin }\end{array}$

photograph does survive of the participants at this meeting, and it was published in Kamminga's (1989) article. Unfortunately, a misprint gave it a date of July 1948 rather than 1946. Those present included David Harker, J. A. A. Ketelaar, Caroline MacGillavry, I. Fankuchen, W. Nowacki and R. W. G. Wyckoff, all of whom were to play prominent roles in the work of the Union. This meeting was my first introduction to the friendly world of crystallographers. Though I was a mere novice with all of 3 months experience in E. G. Cox's chemical crystallography laboratory, I had the temerity to doubt a suggestion made by Fankuchen in a discussion of Fourier syntheses for detecting hydrogen atoms. (Neither of us mentioned difference maps!)

Those present at the scientific meeting in London agreed to the formation of a Provisional International Crystallographic Committee, which met in London on 12 and 13 July 1946 (before the Leeds meeting). There were 31 members from 11 countries. W. L. Bragg and D. Harker were the joint Chairmen, and R. C. Evans was Acting Secretary. The Committee's main decisions were: (i) to create a separate Union of Crystallography; (ii) to create a new journal run by crystallographers; (iii) to continue Structure Reports; (iv) to develop International Tables. This meeting was effectively the 'Zeroth General Assembly of the IUCr'.

A few days later, the new Journal Subcommittee met in Cambridge under the Chairmanship of P. P. Ewald with R. C. Evans as Secretary. The other members were M. J. Buerger, D. Harker, J. A. A. Ketelaar, C. Mauguin (represented by J. Wyart), A. V. Shubnikov and W. H. Taylor. Also present were W. L. Bragg and F. J. M. Stratton (Secretary General of the International Council of Scientific Unions, ICSU). At the suggestion of the Soviet crystallographers, Acta Crystallographica was adopted as the title for the journal. The Editor was to be Ewald, with Evans, Fankuchen, Shubnikov and Wyart as Co-editors.

The Journal Subcommittee also handled the formation of the Union. Bragg and Ewald sought advice from Stratton of ICSU. Draft Statutes and By-laws were prepared. These were approved in correspondence by the Provisional International Crystallographic Committee in March 1947 and then submitted to ICSU. On 7 April 1947, the International Union of Crystallography was formally admitted to ICSU, thus joining the eight Unions who had been members since the 1920s. The Journal Subcommittee then became the interim Executive Committee of the IUCr. 
The 50th anniversary of the Union's admission to ICSU was celebrated on 7 April 1997 when Robert Evans, the original General Secretary and still in fine form at the age of 88 , opened the extensions to the IUCr offices in Chester.

\section{Launch of Acta Crystallographica 1947-1948}

Money had to be raised, and for this the status given by membership of ICSU was vital. It led to grants from UNESCO, and helped in the raising of funds from industrial and other sources in the UK and USA. A publisher had to be found. Cambridge University Press was selected. Manuscripts had to be invited and printed. All these things were accomplished and the journal was launched. Part 1 of Acta Crystallographica bearing the date March 1948 contained 48 pages, as did Part 2 dated May 1948. (I now recall with pleasure that Part 2 contained my first contribution to crystallography, a short note with E. G. Cox on the accuracy of electrondensity maps.) By the time of the Harvard meeting in July, there were another 20 or so papers in the Editors' hands (including the full version of my own paper).

\section{First General Assembly, Harvard, July/August 1948}

A photograph of most of the 310 participants who took part in the scientific sessions at Harvard is reproduced by Kamminga (1989). As to the formal business of the Union, this was transacted without real difficulty, despite Ewald's (1977) story that he sought confirmation of the formation of the Union by the acclamation of the entire audience rather than by the votes of the official delegates. In fact, at that time there were only four members - the Adhering Bodies of Canada, Norway, UK and USA. (Another eight countries had adhered by the end of 1949.) Statutes and By-laws, slightly modified from those submitted to ICSU, were adopted. An Executive Committee, with Sir Lawrence Bragg as President, was elected. Chairmen and members were elected for the several Commissions: Acta Crystallographica (P. P. Ewald), Structure Reports (A. J. C. Wilson), International Tables (K. Lonsdale), Crystallographic Data (F. W. Matthews) and Crystallographic Apparatus (I. Fankuchen).

The size of the IUCr Congresses has grown considerably since 1948 . By 1957, the community was sufficiently established for W. Parrish as Editor to publish a World Directory of Crystallographers. Details of the rise in the number of entries in the last 40 years are shown in Table 1. In recent years, the total has been around 8000 persons in about 70 countries.

\section{Growth of Acta Crystallographica}

Acta has grown in two ways, by increase in the number of pages and by division into sections. In 1996, the
Table 2. Acta Crystallographica

$\begin{array}{lll}\text { Year } & \text { Pages } & \text { Subscriptions } \\ 1948 & 348 & \text { ca } 600 \\ 1953 & 888 & 1270 \\ 1966 & 2273 & 2356 \\ 1969 & 732+2672 & 2291 \\ 1977 & 1046+3974 & 1786 \\ 1981 & 944+2250 & 1577 \\ 1983 & 950+770+1714 & 1468 \\ 1993 & 901+1075+2186+604 & 1256 \\ 1996 & 1010+1078+3262+1246 & 1075\end{array}$

Note. From 1969 onwards, the number of subscriptions is for Section A.

number of pages was twenty times the 348 pages printed in 1948. By 1993, a fourth section was needed, namely Section $D$ for Biological Crystallography. Details of these features are given in Tables 2 and 3. Table 2 also shows the number of subscribers. In the early years, the number of subscriptions grew steadily and reached 2356 by 1966 . The demand for back numbers was such that the stocks of the earliest issues, based on a print order of 2000 , ran out. Some volumes had to be reprinted. But from 1968 onwards, the sheer size and hence cost of the volumes caused a slow decline in the sales. If 1996 is compared with 1966, it will be seen that the number of pages has tripled but the number of subscriptions has halved. Inevitably, serious financial problems have arisen. Of course, many other scientific journals have met similar difficulties.

Difficulties arose even in the earliest years of Acta owing to the rapid influx of acceptable manuscripts. The story is detailed in Kamminga (1989, pp. 591-593). But in outline it runs as follows. In 1951, Cambridge University Press was unable to handle more material, and transfer to Munksgaard in Copenhagen from 1952 was negotiated by Ewald. However, an increase in size had not been accompanied by an increase in subscription price, and in 1953 Acta was running at a loss. In 1953-1954, Bijvoet, then President of the Union, proposed a cheaper Dutch publisher. However, Ewald as Editor and Evans as Technical Editor were unhappy about a further change of publisher. The new Executive Committee in October 1954 approved a transfer to Oosthoek in the Netherlands. Ewald and Evans then expressed their wish to resign. Wyckoff as new President did not wish the crisis to deepen and decided that any change of publisher should be delayed for further investigations. In the end no change was made. In 1956, the workload on Ewald and Evans was lightened by the appointment of two additional Co-editors, H. Lipson and E. W. Hughes. (By the time he retired in 1978, Henry Lipson, with the clerical assistance of his wife Jenny, had handled more than 4000 papers, probably far more than any other Co-editor.)

In 1960 after 12 years as Editor, Ewald was succeeded by A. J. C. Wilson. The later successors were S. C. 
Abrahams in 1978, C. E. Bugg in 1987 and J. R. Helliwell in 1996. Paul Ewald and Arthur Wilson were two longserving giants in the service of the Union. Ewald's direct involvement began in 1947 when he was Chairman of the interim Executive Committee and ended in 1966 as Past President. His Review of his papers on Crystal Optics 1912 to 1968 was published in Acta in 1979 after his 90th birthday. Wilson began in 1948 as Editor of Structure Reports, continued as Editor of Acta, served as Vice-President 1978-1981, and then as Editor of International Tables until 1993. Fig. 1 is an informal photograph of the two of them taken at the 1962 Munich meeting which commemorated the 50th anniversary of the discovery of X-ray diffraction by von Laue and his assistants.

Robert Evans continued as Technical Editor until 1958 when he was succeeded by R. W. Asmussen of Copenhagen. However, the load became impossible to manage on an honorary basis, and the post was advertised for a full-time professional. S. A. Bryant was appointed in 1962, and he worked initially in the spare room of his house in Chester, England. By this accident, the Union's offices came to be located in Chester. The editorial staff has had to be increased steadily to cope with mounting work. Bryant retired at the end of 1975 and was succeeded by D. W. Penfold from 1976 to 1985. M. H. Dacombe then took over until 1993, when he was appointed Executive Secretary of the IUCr. The current Managing Editor is P. R. Strickland who heads a staff of 19. They handle 6 journal titles and other publications.

\section{Journal of Applied Crystallography and the expansion of Acta Crystallographica}

By 1963, the need for a journal dealing with applied crystallography became apparent. The Rome General Assembly in that year authorized the Executive Committee to make preparations for such a journal with W. Parrish as the likely Editor. Unfortunately, by 1965

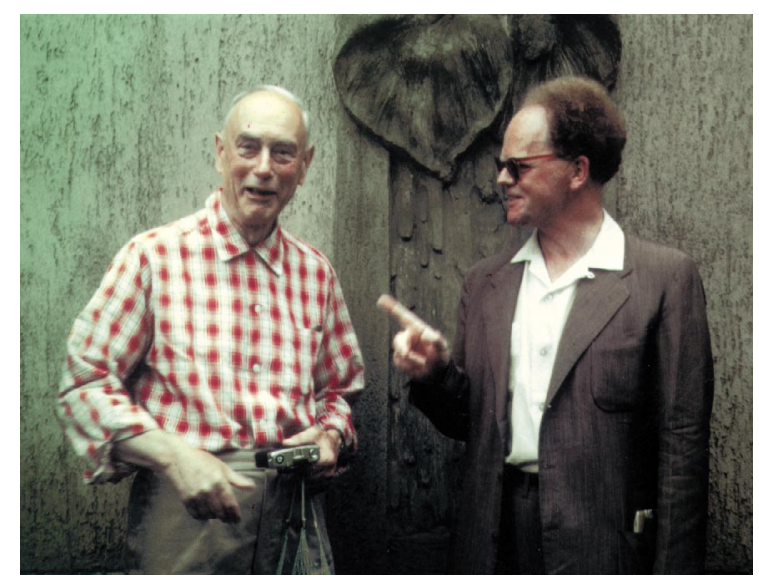

Fig. 1. Paul Ewald (left) and Arthur Wilson (right) in Munich 1962.

\section{Table 3. Sections of Acta Crystallographica}

1948 Journal launched

1968 A: Crystal Physics, Diffraction, Theoretical and General Crystallography

B: Structural Crystallography and Crystal Chemistry

1983 A: Foundations of Crystallography

$B$ : Structural Science

C: Crystal Structure Communications (incorporating Nardelli's journal started in 1972)

1993

D: Biological Crystallography

Parrish reported that he was unable to continue with the preparations.

The matter surfaced again at the 1966 Moscow General Assembly. But by then a new problem had arisen with Acta. The number of structural papers had risen rapidly and it was felt that the more physical papers were being deterred by the changing image. Thus there were proposals either for a new Journal of Crystal Physics or for an $A / B$ split of Acta into physical and structural sections. These proposals had possible repercussions for the proposed $J A C$, for which A. Guinier was now ready to act as Editor.

The Moscow General Assembly then authorized the Executive Committee to act on the proposals of a Publications Sub-committee which was to examine these problems in detail. The new Executive Committee met in Moscow on 20 July 1966 and appointed the new IUCr Treasurer D. W. J. Cruickshank (convenor), J. M. Cowley, A. Guinier and A. J. C. Wilson as the Publications Sub-committee. They were given a rather free brief and an implicit indication that they were to get things moving. After various meetings, consultations and financial analyses in 1966-1967, including discussions with printers and publishers together with a questionnaire sent to about 100 crystallographers, the Subcommittee recommended in July 1967 that Acta Crystallographica be split into two sections and that $J A C$ be launched. This recommendation, together with new subscription rates, was accepted by the Executive Committee in a postal ballot, and the new style Acta appeared at the beginning of 1968. Indeed, Acta $A$ and Acta $B$ got off to flying starts with large issues dedicated to Ewald for his 80th birthday. The first issue of $J A C$ followed shortly after.

However, in the postal ballot, the Executive Committee had not been unanimous. Two members, B. E. Warren and W. H. Zachariasen, voted to delay the division of Acta until there had been a full discussion in person at the Executive meeting due in 1968. They were also worried about financial risks. Actually there had been considerable discussion in Moscow in 1966. Reference to the minutes of the EC meeting on 20 July 1966, when the Sub-committee was given its instructions, shows that these two members had been unavoidably absent. After the postal ballot, Kathleen Lonsdale, as Past President, was firm in advising the new Treasurer 
and General Secretary to proceed with the necessary arrangements with Munksgaard. On the financial questions, she wrote to Boom on 21 August 1967, 'If I had allowed myself to be deflected by such arguments when we were launching International Tables they would never have been published'. In fact, the finances worked out well in 1968.

The incident pointed up a weakness in the working of the EC. Until 1969, the By-laws only required that the EC meet at least once between General Assemblies. Partly this was a question of keeping down expenditure. After 1969, the By-laws were altered so that at least two meetings were required between General Assemblies. In any case, the increasing volume of Union business made this essential.

The general rise in the size of $J A C$ over the years together with the slow decline in the number of subscriptions is illustrated by the following figures: 1969 , 312 pages, 1125 subscriptions; 1977, 510 pages, 1169 subscriptions; 1996, 759 pages, 868 subscriptions. In 1997, owing to the inclusion of papers from a conference on small-angle scattering, the number of pages reached 1191. The Editors in charge have been A. Guinier (1968-1969), R. A. Young (1970-1978), M. Hart (19781984), M. Schlenker (1984-1990) and A. M. Glazer (from 1990).

In recent years, synchrotron radiation has proved an outstanding tool in many branches of science, especially crystallography. Accordingly, in October 1994, the IUCr launched the Journal of Synchrotron Radiation, with S. S. Hasnain, J. R. Helliwell and H. Kamitsubo as Editors.

The present Commission on Journals, which embraces Acta Crystallographica, Journal of Applied Crystallography and Journal of Synchrotron Radiation, now has a membership of over 100 Editors and Co-editors. This reduces the average editorial load to less than 100 published pages per year. Henry Lipson's comments on such arrangements would have been interesting.

\section{Scientific content of the journals}

Many famous papers have been published in IUCr journals or presented at IUCr meetings. At the risk of causing offence to others, I mention a few of my own favourites. In 1966, Jerome and Isabella Karle, shown together in Fig. 2, published in Acta their paper on symbolic addition for centrosymmetric and noncentrosymmetric structures. This became a Citation Classic of the Institute for Scientific Information. By 1975, it had already been cited 946 times.

The paper by D. Harker and J. S. Kasper on phase determination through inequalities appeared in the second issue of Acta in May 1948. The May issue of 1950 carried a paper in which inequalities were expressed in determinantal form. This was the first of many outstanding papers in Acta on phase determination by
Jerome Karle and Herbert Hauptman. They were awarded the Nobel Prize for Chemistry in 1985.

An early issue of $J A C$ in 1969 had another classic, H. M. Rietveld's paper on a profile refinement method in neutron powder diffraction. This led to an enormous improvement in the power of powder diffraction for structure analysis for both neutron and X-ray diffraction.

The 11 September 1974 issue of the ISI's Current Contents carried an article on Acta Crystallographica by Eugene Garfield in his series of Journal Citation Studies. He wrote 'Acta Crystallographica can justifiably take pride in its impact on science. The $45[$ Acta] papers listed here stand high in a list of 6000 papers in science cited 100 times or more in 1961-1972'. These 45 papers ranged over scattering factors, phase relations, statistics (including accuracy), thermal motion, extinction and some crystal structures.

\section{International Tables}

Counting the two 1935 volumes of Internationale Tabellen as the first series, the IUCr has published the second and third series. International Tables for X-ray Crystallography began with Volume I on Symmetry Groups in 1952. Three further volumes and several new editions followed. The third series, International Tables for Crystallography, began with Volume A in 1983. Some details of both series with dates, titles and sales to the end of 1995 are given in Table 4.

Many authors have contributed to the outstanding success of the International Tables. It can be seen from Table 4 that the total sales of the space-group volumes I, A and Brief A - have exceeded 20000 . Clearly, the Tables have met a great professional need, and the whole endeavour has been a truly remarkable achievement in international collaboration during the last 50 years.

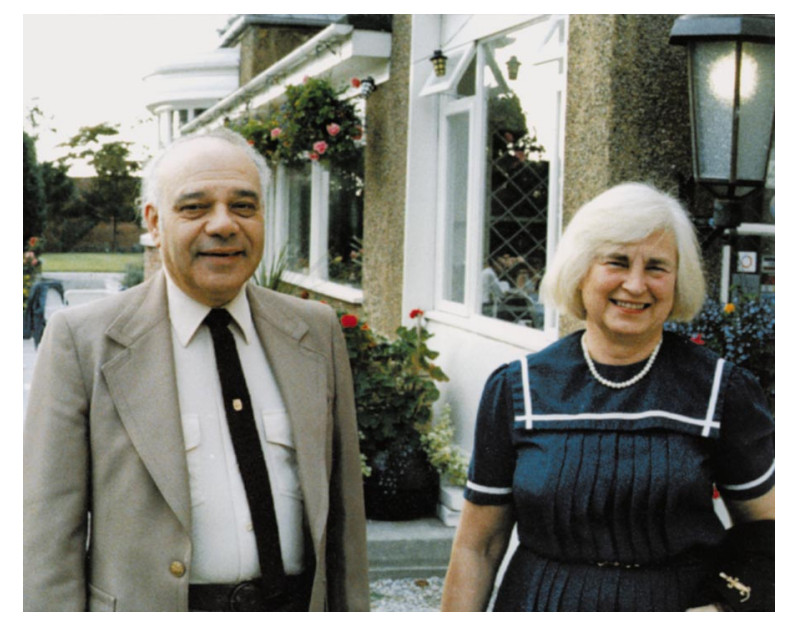

Fig. 2. Jerome and Isabella Karle, whose 1966 paper on symbolic addition became a Citation Classic, at Chester 1985. 
Table 4. International Tables

First edition
1952
1959
1968
1974
1983
1985
1993
1992

Volume
I
II
III
IV
A
Brief A
B
C

Title
Symmetry Groups
Mathematical Tables
Physical and Chemical Tables
Revised and Supplementary Tables
Space-Group Symmetry
Space-Group Symmetry
Reciprocal Space
Mathematical, Physical and Chemical Tables

Editors

N. F. M. Henry \& K. Lonsdale

J. S. Kasper \& K. Lonsdale

J. A. Hamilton

Th. Hahn

Th. Hahn

U. Shmueli

A. J. C. Wilson

Sales to Dec 1997

9501

8764

4268

6434

4856

1552

1798
The General Editors leading the teams have been K. Lonsdale (1948-1963), N. F. M. Henry (1963-1972), Th. Hahn (1973-1982). A. J. C. Wilson (1982-1993) and Th. Hahn again from 1993.

When Kathleen Lonsdale retired in 1963, Norman Henry took over to begin preparations for the new third series. A key feature of this was the Computer Trial Project on which D. S. Fokkema was employed from 1971. The aim was to do all the mathematics of the symmetry features of the 230 space groups de novo by computer. The task was completed by December 1978 when a complete print layout of the 17 plane groups and 230 space groups was ready for transfer to computer typesetting.

\section{Structure Reports}

The original aim of Structure Reports was to extract the structural information from each paper so thoroughly (and critically) that there would be little need to consult the original paper (possibly published in an inaccessible journal). The material for the years 1913-1939 had already been covered by the pre-war Strukturbericht.

The Chairmen of the Structure Reports Commission were A. J. C. Wilson (1948-1960), W. B. Pearson (19601972), J. Trotter (1972-1981) and G. Ferguson (19811993). There were numerous Co-editors and Abstracters. Initially, Arthur Wilson was assisted by three Section Editors: C. S. Barrett (Metals), J. M. Bijvoet (Inorganic Compounds) and J. M. Robertson (Organic Compounds). A photograph of Robertson taken in 1969 is shown in Fig. 3.

As the source literature, which started in 1940, grew and grew, the task became increasingly mammoth. The reporting ran several years late. Nevertheless, enormous efforts were made. In 1966, 18 Co-editors and their Abstracters were working simultaneously. The efforts paid off. In the bumper year of 1975, 14 volumes were published.

From 1975 onwards, external numeric databases began to enter the picture, particularly for organic and organometallic structures at the Cambridge Crystallographic Data Centre under Olga Kennard. It took some years for such electronic databases to be fully running and conveniently accessible, but they became the only way of handling the flood of structures that poured in their many thousands into the literature. Consequently, the need for Structure Reports diminished. The Commission was finally disbanded at the Beijing General Assembly in 1993 after the publication of the volumes covering organic structures to 1985, metals and inorganic structures to 1990, and a complete index for metals and inorganic structures from 1913 to 1990.

The remarkable labours of this Commission lasted 45 years from 1948. Sales of Structure Reports volumes were around $800-900$ at their peak, falling finally to around 500 .

\section{Growth of other activities}

The number of nonpublishing Commissions has now risen to 15. The Apparatus Commission, which was one of those started in 1948, did particularly good work until it was replaced in 1996 by the Commission on High Pressure, which had begun as a subgroup within the Apparatus Commission. The Union has played a part in publishing more than 20 crystallographic books.

The most striking of the nonpublishing activities of the Union has been the arrangement of the triennial scientific Congresses and of intermediate specialized meetings. All such meetings have depended on the hard work and skills of their programme and organizing committees. The Congresses grew from 310 crystal-

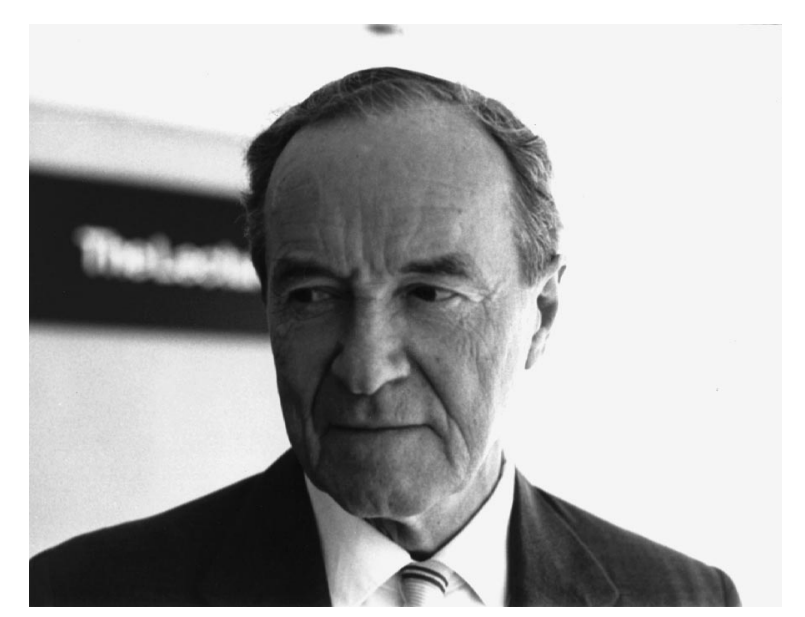

Fig. 3. J. M. Robertson, Organic Section Editor of Structure Reports, at Stony Brook 1969. 
Table 5. Presidents and General Assemblies at which they were elected

$\begin{array}{lll}\text { Year } & \text { President } & \text { Place } \\ {[1947]} & \text { [P. P. Ewald] } & \\ 1948 & \text { W. L. Bragg } & \text { Harvard } \\ 1951 & \text { J. M. Bijvoet } & \text { Stockholm } \\ 1954 & \text { R. W. G. Wyckoff } & \text { Paris } \\ 1957 & \text { J. Wyart } & \text { Montreal } \\ 1960 & \text { P. P. Ewald } & \text { Cambridge } \\ 1963 & \text { J. D. Bernal } & \text { Rome } \\ 1966 & \text { K. Lonsdale } & \\ 1969 & \text { N. V. Belov } & \text { Moscow } \\ & \text { A. Guinier } & \text { Stony Brook }\end{array}$

lographers at Harvard (1948) and 340 at Stockholm (1951), where there were 230 papers, to around 900 participants at Cambridge (1960). Moscow (1966) had about 3000 registrants, the largest ever. From Kyoto (1972) to Hamburg (1984), the attendances were around 1400. There were slightly smaller figures at Perth (1987) and Beijing (1993), but Bordeaux (1990) attracted 1832 and Seattle (1996) 2311 crystallographers from 51 countries. There were also 150 exhibitors at Seattle. The Seattle program included lectures and a roundtable discussion by 8 Nobel Laureates: B. N. Brockhouse, J. Diesenhofer, H. Hauptman, J. Karle, J. C. Kendrew, W. N. Lipscomb, H. Michel and C. G. Shull. Between the Beijing Congress in 1993 and the Seattle Congress in 1996, the Union was a sponsor of over 40 other meetings and was able to assist several hundred young scientists to attend these meetings.

Curiously, neither Ewald (1944) in his original proposal nor the committees of 1946-1947 nor the first Statutes of 1948 mentioned the organizing of international conferences as a purpose for the Union. Yet such conferences have powerfully advanced the science of crystallography and have greatly benefited their participants - often through personal contacts and discussions. The point was not covered formally until the Statutes of 1957.

Since 1947, the IUCr has continued its fruitful membership of ICSU. It has supported, and been helped by, the ICSU Statement on Freedom in the Conduct of Science. ICSU now has 25 Scientific Union members plus 95 scientific academy or research council members and 28 Scientific Associates. Thanks to its vigorous publication programme, the IUCr possibly has the largest financial turnover of any Union.

At the Harvard meeting in 1948, the formal membership of the IUCr consisted of just 4 Adhering Bodies (National Academies, National Research Councils etc.), those for Canada, Norway, UK and USA. By the time of the Stockholm meeting in 1951, there were Adhering Bodies for another 14 countries: Australia, Belgium, Brazil, Czechoslovakia, Denmark, France, India, Italy, Japan, Netherlands, South Africa, Spain, Sweden, and Switzerland. By 1954, Austria, Chile, the German Federal Republic and the USSR were also members.

$\begin{array}{lll}\text { Year } & \text { President } & \text { Place } \\ 1972 & \text { D. C. Hodgkin } & \text { Kyoto } \\ 1975 & \text { A. Magnéli } & \text { Amsterdam } \\ 1978 & \text { N. Kato } & \text { Warsaw } \\ 1981 & \text { J. Karle } & \text { Ottawa } \\ 1984 & \text { Th. Hahn } & \text { Hamburg } \\ 1987 & \text { M. Nardelli } & \text { Perth } \\ 1990 & \text { A. Authier } & \text { Bordeaux } \\ 1993 & \text { P. Coppens } & \text { Beijing } \\ 1996 & \text { E. N. Baker } & \text { Seattle }\end{array}$

The subsequent adherences were: 1960, Argentina, Finland, Israel, New Zealand; 1963, Hungary; 1966, Poland, Yugoslavia; 1978, China (People's Republic), Egypt; 1981, Portugal; 1984, Mexico; 1987, Bulgaria; 1993, Venezuela; 1996, China (Taipei), Korea (Republic).

Political changes have brought changes in the Adhering Bodies. Thus, in 1993, the former USSR was replaced by Russia and Ukraine, and the former Yugoslavia by Croatia, Serbia and Slovenia. On the other hand, the Czech and Slovak Republics adhered through a single Regional Committee. For the complex history of German adherence between 1953 and 1968, see Kamminga (1989). By 1968, the BRD and the DDR were adhering separately. From 1993, after the reunification of Germany, there has been a single Adhering Body, the Deutsche Gesellschaft für Kristallographie. Pakistan adhered to the Union from 1963 but withdrew in 1969. There are now 40 Adhering Bodies. They and their National Committees are listed in Annex IV to the Report of the Seattle meeting [Acta Cryst. (1997), A53, 692-748].

\section{Organizational structure and legal status of the Union}

As just mentioned, the members of the Union are the Adhering Bodies for each country. The work of the Union is directed by the triennial General Assemblies. This work has been carried forward, through the Union's Officers and Commissions, by numerous very dedicated individuals. The Officers are the members of the Executive Committee, currently 10 persons.

Table 5 lists the Presidents of the Union and the places of the General Assemblies where they were elected. There was an unusual occurrence in 1966. J. D. Bernal, who had been elected President in 1963, was unable to come to the Moscow General Assembly owing to serious ill health and resigned a month before the meeting. Accordingly, by By-law 2.3, Kathleen Lonsdale, as senior Vice-President, assumed the office of President and presided at the meetings in Moscow. N. V. Belov was elected as President for the next triennium in the usual way at the end of the General Assembly. 
As an illustration of the international character of the Union, Fig. 4 shows the retiring President, André Guinier, and the incoming President, Dorothy Hodgkin, at the Kyoto meeting in 1972.

Robert Evans did sterling work as General Secretary of the Union from its inception until 1954. He was succeeded by D. W. Smits (Fig. 5), who served with great dedication for the 12 years 1954-1966. Since then there has been a limitation to a maximum of 9 years. By the time Smits retired, the task had become too much for one person and the post was split between a General Secretary and a Treasurer. In Moscow, G. Boom was elected General Secretary and I was elected Treasurer. Despite Kathleen Lonsdale's assurances that the work

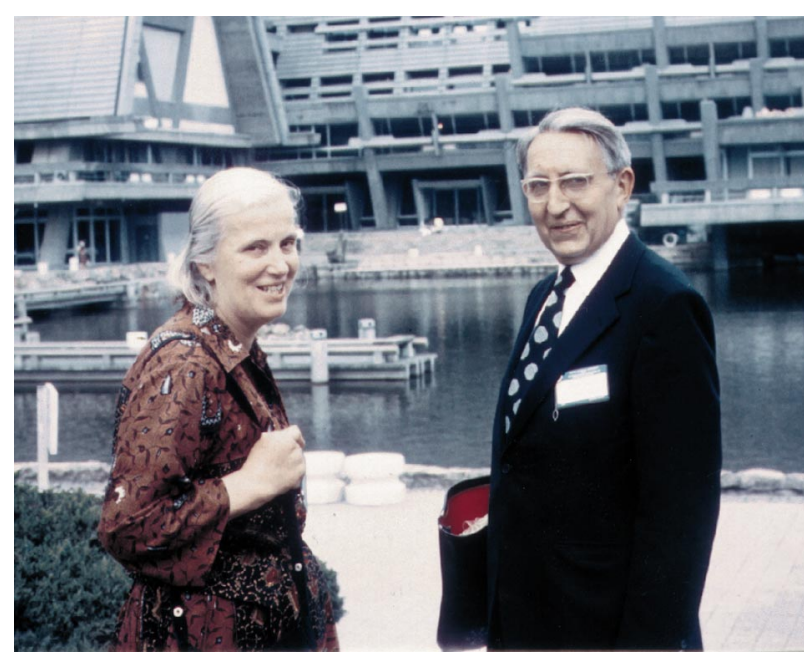

Fig. 4. André Guinier, retiring President, and Dorothy Hodgkin, incoming President, at the Kyoto meeting 1972.

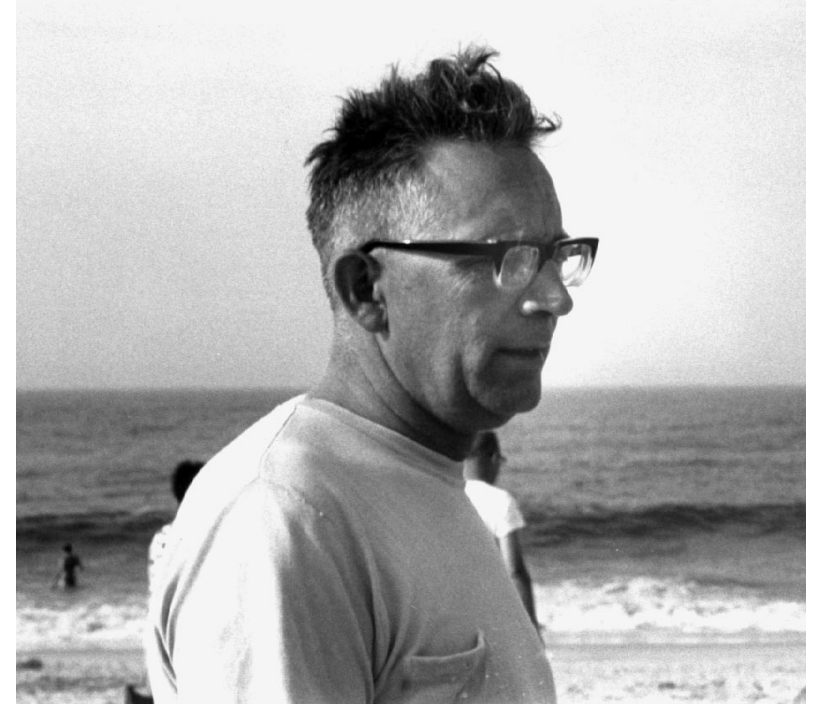

Fig. 5. Donald Smits, General Secretary 1954-1966, at Stony Brook 1969. loads would not be heavy, Geert Boom and I both found that the amount of day-to-day work involved in the running of the Union surpassed acceptable levels. Accordingly, the Executive Committee at their meeting in June 1968 agreed to the appointment of a salaried full-time Executive Secretary. The post was advertised and Dr J. N. King was appointed from 1 February 1969.

Jim King, portrayed in Fig. 6, served the Union with much success for 24 years until his death in April 1993 at the early age of 55 . He had an excellent appreciation of the international character of the Union, and understood how to balance different ways of looking at things, whether depending on personalities or different cultural backgrounds. His obituary will be found in Acta Cryst. (1993), A49, 683-684.

Once Jim King was sufficiently experienced as Executive Secretary, Geert Boom was able in 1970 to step down as General Secretary, and I was given the combined office of General Secretary and Treasurer. The successive holders of the combined office have been S. E. Rasmussen (1972-1981), K. J. V. Kurki-Suonio (1981-1987), A. I. Hordvik (1987-1995) and S. Larsen, who took over in 1995 after Hordvik's death.

When I became Treasurer in 1966, I learnt that the Union was unincorporated and lacked legal personality. Thus in any disputes with publishers or employees, individual Officers of the Union might become personally liable. The Union itself could not enter into contracts. Also there were serious taxation risks. Thus there was need for incorporation and a permanent legal domicile for the Union.

Other scientific Unions had faced this problem and several had incorporated. Careful enquiries showed that Switzerland was the country best suited to the Union's need and that the Union could probably incorporate there with relatively little trouble. This proved to be the

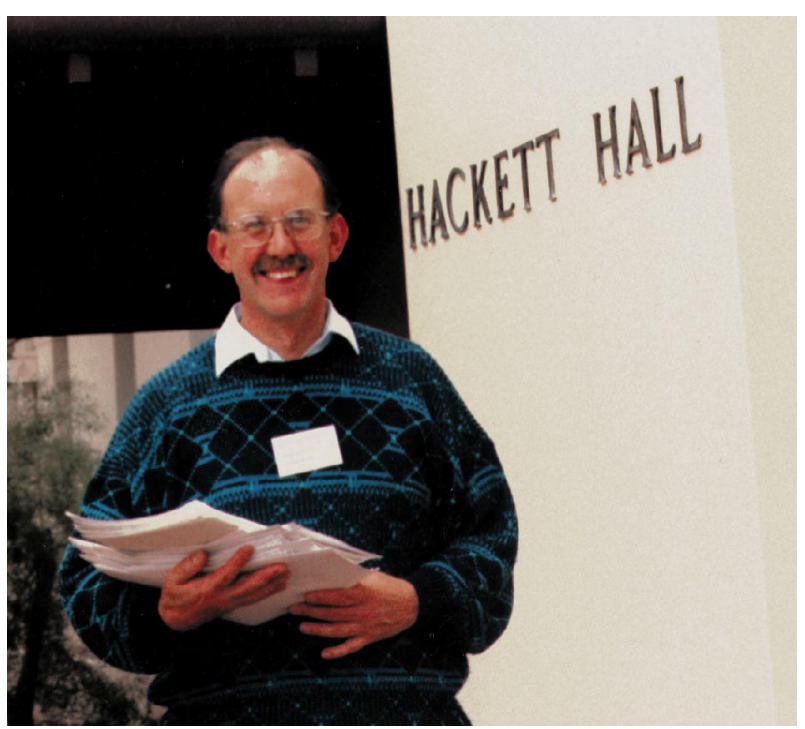

Fig. 6. Jim King, Executive Secretary 1969-1993, at Perth 1987. 
case. Fig. 7 shows Geert Boom and myself at dinner in Geneva on 28 February 1969. The picture is symbolic, not for any refreshments on the table, but for the squat little book in the foreground. This a copy of the Swiss Civil Code. We had spent the afternoon in Geneva with a Swiss lawyer who had explained that the Union's needs could be met by incorporation as an Association governed by Articles 60 and following of the Swiss Civil Code. As we walked away in the early evening through the streets in the legal quarter of Geneva, we passed a bookstall where we bought a copy of the Civil Code. We studied it during our dinner and confirmed that Articles 60 and following were very suitable for the Union (or indeed for a mountain village yodelling club!). An important feature of the Swiss Civil Code was that it did not require the frequency of the General Assemblies to be changed from triennial to annual.

The Stony Brook General Assembly of 1969 resolved that the Union be incorporated and domiciled in Geneva. The legal processes were finally completed with the registration of the Union at the Commercial Registry in Geneva on 24 February 1972. The Union received exemption from Swiss federal and cantonal taxation, and could then make use of the Double Taxation Agreements between Switzerland and other countries.

\section{IUCr finances}

Money is essential. Outside support was necessary to launch Acta, and a continuing healthy balance is vital for the work of the Union. The largest part of the Union's income comes from sales of publications. Table 6 gives some year-end balances for the Union's total funds. In examining this table, one must remember the continuous inflation and the fluctuations in exchange rates between the several currencies in which the Union operates.

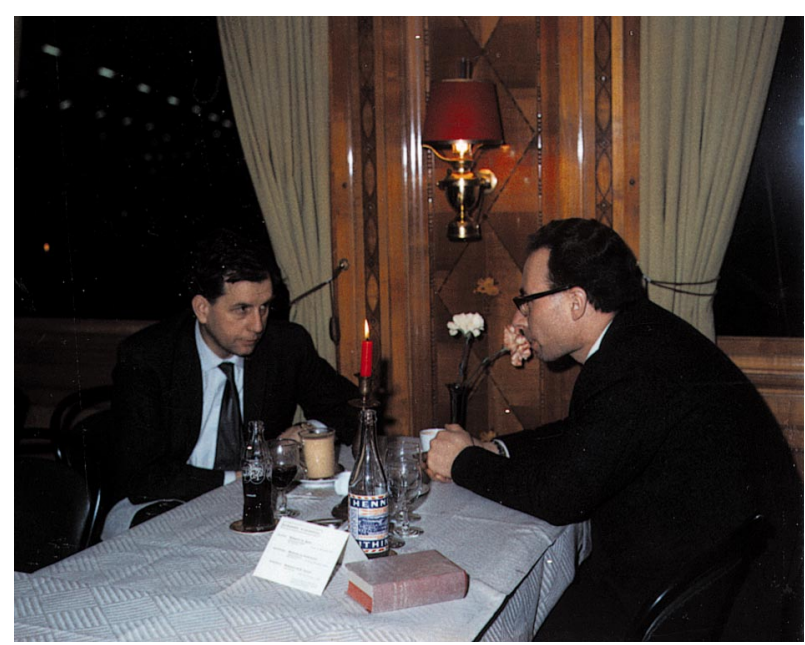

Fig. 7. Durward Cruickshank (left) and Geert Boom (right) discuss the Swiss Civil Code (foreground) in Geneva, February 1969.
Table 6. IUCr year-end balances

$\begin{array}{ll}\text { Year } & \text { Balance } \\ 1965 & \$ 169 \mathrm{k} \\ 1979 & \$ 839 \mathrm{k} \\ 1980 & \$ 590 \mathrm{k} \\ 1981 & \$ 403 \mathrm{k} \\ 1982 & \$ 565 \mathrm{k} \\ 1985 & \$ 1737 \mathrm{k} \\ 1997 & \$ 5035 \mathrm{k}\end{array}$

There was a fairly steady build up of funds up to 1979 , but a deepening financial crisis in 1980 and 1981. This was due largely to rising printing costs for the journals. Such problems had been apparent for some time, and from 1978 the possibility of setting up an in-house computerized typesetting system was seriously explored. This would have involved a capital expenditure of several hundred thousand dollars. Some preliminary expenditure was incurred in 1980 . However, the journal accounts for 1980 showed heavy losses which wiped out the possibility of going ahead with the in-house project. The main cause for the unhappy financial development during 1980 was a sharp increase in the exchange value of the British pound against the Danish krone. The Union was paying British printers in pounds, but receiving subscriptions through Munksgaard in kroner. Some difficulties continued in 1981. \{Svend Rasmussen in Appendix $\mathrm{C}$ of the Report of the Ottawa General Assembly [Acta Cryst. (1983), A39, pp. 452-455] gives details.

After the Ottawa meeting, the incoming General Secretary and Treasurer, Kaarle Kurki-Suonio was given the advisory support of a Finance Committee. Three important steps resulted: (i) a new agreement was negotiated with Munksgaard on much better terms for the Union; (ii) the publication costs were set in Danish

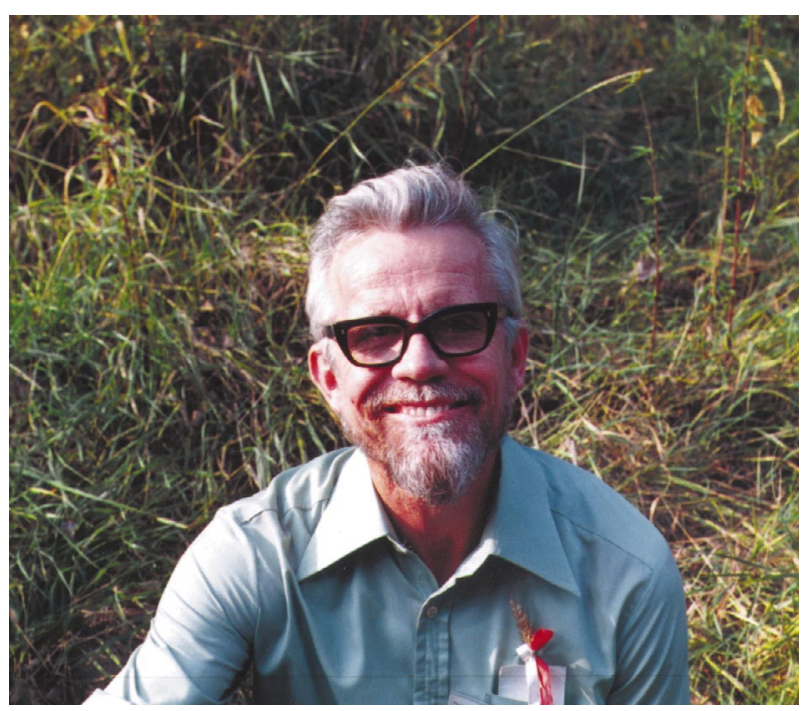

Fig. 8. Ted Maslen, a leader of the IUCr into the electronic era, at Perth 1987. 
kroner; and (iii) large price rises were imposed on the subscriptions. These three actions turned Acta into a large profit-maker and meant that there was no need to increase the price of Acta again until 1990. This period provided the main increase in the IUCr's wealth and made possible much good work by the IUCr. [See Report of the 1993 General Assembly, Acta Cryst. (1995), A51, p. 600.]

A rosy financial future for the Union is not a certainty. Inflation is a constant problem. Currency fluctuations can be serious. Between 1984 and 1995, the US dollar halved in value against the Swiss franc. Technical developments in publications and communications are occurring at a furious pace. The Treasurer, the Finance Committee and the Editors will need to be very alert.

\section{Paul Ewald 1888-1985}

In addressing the Opening Ceremony in Moscow in 1966, Kathleen Lonsdale said that, more than any one other man, she considered Professor Ewald as the founder of the Union. I concur. For an appraisal of the man and his scientific work, see the memorial volume P. P. Ewald and his Dynamical Theory of X-ray Diffraction (Cruickshank et al., 1992).

At his death, Ewald left a bequest to the Union. Augmented by a further donation from his family and by a donation from the Union, the Executive Committee decided to establish the Ewald Prize for outstanding contributions to the science of crystallography. To date, the winners of the Ewald Prize have been: 1987, J. M. Cowley and A. F. Moodie; 1990, B. K. Vainstein; 1993, N. Kato; 1996, M. G. Rossmann.

\section{The electronic future for publishing and information}

A separate paper would be needed to provide a proper history of the Union's involvement in electronic publishing and information in the last 20 years, let alone to make any predictions as to the future when computer and communications technology is developing so rapidly. But a few points should be made.

A Working Party on Information Services, under Svend Rasmussen as Chairman, was set up in 1972 and reported to the General Assembly in Amsterdam in 1975. The study of computerized typesetting began in 1978, but the project had to be cancelled in 1981 because of financial difficulties. A large gift from Japanese crystallographers at that time funded a computer which greatly assisted many editorial operations in the Chester office.

The build up of the IUCr balances after 1983 allowed the creation of a Publications and Journals Development Fund. From 1988 onwards, there was substantial expenditure in Chester on computer equipment and software, and on programming and development. The office was linked to the global e-mail network in 1990.
Thanks to the work of S. R. Hall, F. H. Allen and I. D. Brown, the Crystallographic Information File (CIF) has been developed as a standard file suitable for the archiving and transmission of crystallographic data. Acta Crystallographica Section $C$ is now produced solely from CIF submissions. Section D will shortly be available online, and will be followed soon by other IUCr journals. The World Directory of Crystallographers is already available on-line.

Of the 17 editorial staff in Chester, four form the research and development team, which is headed by Brian McMahon. Apart from maintaining and improving the office computer network, they work on increasing the use of new technology and on expanding the facilities of the IUCr pages on the World-Wide Web.

Among the crystallographers who have worked on leading the IUCr into the new technologies, one may be singled out, E. N. Maslen (Fig. 8). Sadly, he died suddenly on 2 Februrary 1997 at the age of 61. In his role as Chairman of the Working Party on Crystallographic Information (1987-1990), then as Director of Archiving and Crystallographic Information (1990-1993) and then as Chairman of the Committee on Electronic Publishing, Dissemination and Storage of Information (1993-1997), 'Ted guided the IUCr's publication and archiving activity into the electronic era through a tangled maze of options and opinions' (Executive Committee Report for 1996).

I was a novice and peripheral observer of the conception of the Union in 1946. The science of crystallography has flourished greatly in the last 50 years. Through its publications and congenial meetings, the International Union of Crystallography has played a major part in enabling that scientific flowering. The science shows no signs of running short of striking advances in the future. Thus, the Union will not lack for challenges.

The illustrations in this paper have been taken from the IUCr collection in Chester. Thanks are due to the original (sometimes unknown) photographers.

\section{References}

Cruickshank, D. W. J., Juretschke, H. J. \& Kato, N. (1992). Editors. P. P. Ewald and his Dynamical Theory of X-ray Diffraction. Oxford: IUCr/Oxford University Press.

Ewald, P. P. (1944). Nature (London), 154, 628-631.

Ewald, P. P. (1962). Editor. Fifty Years of X-ray Diffraction. Utrecht: Oosthoek.

Ewald, P. P. (1977). Acta Cryst. A33, 1-3.

Kamminga, H. (1989). Acta Cryst. A45, 581-601.

Kamminga, H. (1992). P. P. Ewald and his Dynamical Theory of X-ray Diffraction, edited by D. W. J. Cruickshank, H. J. Juretschke and N. Kato, pp. 39-43. Oxford: IUCr/Oxford University Press.

McLachlan, D. Jr \& Glusker, J. P. (1983). Editors. Crystallography in North America. New York: American Crystallographic Association. 